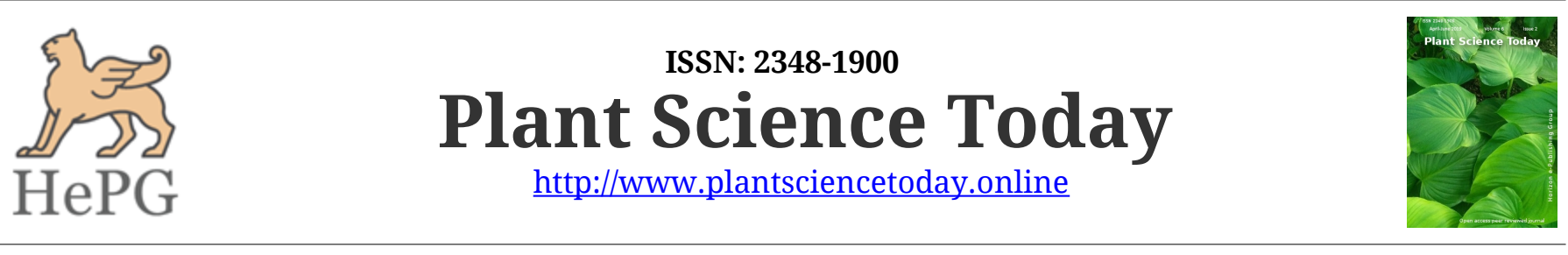

OPEN ACCESS

Research Article

\title{
Effect of nitrogen application on the phytochemical production in Jatropha curcas $L$. Euphorbiaceae) during drought conditions (Angiosperms:
}

\author{
Adewole Adebusola ${ }^{1}$, Odjegba Victor ${ }^{1}$, Iwuala Emmanuel ${ }^{2} \&$ Afroz Alam $^{3^{*}}$ \\ ${ }^{1}$ Department of Botany, University of Lagos, Lagos State, Nigeria \\ ${ }^{2}$ Department of Plant Science and Biotechnology, Federal University, OyeEkiti, Nigeria \\ ${ }^{3}$ Department of Biotechnology, Banasthali Vidyapith, India
}

\section{Article history}

Received: 06 March 2019

Accepted: 11 April 2019

Published: 27 April 2019

\section{Publisher}

Horizon e-Publishing Group

\author{
*Correspondence \\ Afroz Alam \\ \afrozalamsafvi@gmail.com
}

\begin{abstract}
Nitrogen is an important nutrient for the successful metabolism of plants, but its occurrence in soil is always very limited. This nutrient has a significant role to preserve plants during various stress conditions by altering the production rate of phytochemicals as defense weapons. Hence, this study was carried out to analyze the effect of nitrogen supply on the phytochemical composition and relative water content in Jatropha curcas L. under a simulated drought condition. The selected seedlings were grown from stem cuttings and categorized into different treated three groups along with the control. After the completion of the experiment, the growth pattern and phytochemical production were investigated. An increased malondialdehyde activity (MDA) was reported with a reduction in relative water content (RWC) of the leaf and in the biomass of seedlings under drought stress. A significant decrease in the levels of alkaloids, phenol, flavonoids and tannins with an increase in saponins and terpenoids was also observed in only simulated drought stressed plants. While a significant increase in the levels of total alkaloid, tannins, flavonoids and phenols was observed in those plants where exogenous nitrogen was supplied before the start of drought periods, unlike in treated and control plants. Therefore, it was revealed that application of Nitrogen enabled the plants to possess protective mechanism through the production of phytochemicals that facilitate the cell membrane to reduce the detrimental effects caused by drought stress.
\end{abstract}

Keywords: drought; Jatropha curcas; phytochemical; defense response; nitrogen.

Citation: Adebusola A, Victor O, Emmanuel I, Alam A. Effect of nitrogen application on the phytochemical production in Jatropha curcas L. (Angiosperms: Euphorbiaceae) during drought conditions. Plant Science Today 2019;6(2):183-189. https://doi.org/10.14719/pst.2019.6.2.523

Copyright: (C) Adebusola et al (2019). This is an open-access article distributed under the terms of the Creative Commons Attribution License, which permits unrestricted use, distribution, and reproduction in any medium, provided the original author and source are credited (https://creativecommons.org/licenses/by/4.0/).

Indexing: Plant Science Today is covered by Scopus, CAS, AGRIS, CABI, Google Scholar, etc. Full list at http://www.plantsciencetoday.online

\section{Introduction}

Plants are sessile in nature and have adapted well to various stress conditions. The abiotic factor drought is one of the detrimental stresses which limit crop yield worldwide. The onset of drought occurs slowly and develops severe intensity with time duration which results in both morphological 
and physiological damages (1). The effect of drought is mostly linked with the reduction in photosynthetic efficiency due to the reduction in the leaf lamina expansion, which causes early senescence of leaf and decreased food production (2). Under drought stress conditions, oxidative stress occurs which leads to the development of reactive oxygen species (ROS) such as alkoxy radicals (RO), catalase (CAT), gluthatione reductase (GR) and ascorbate peroxidase (APX) $(3,4)$.

Nitrogen is a vital component of cellular constituents. Alkaloids, amides, amino acids, proteins, DNA, RNA, chemicals, nutrients, hormones and numerous other cell complexes contain nitrogen as one of there components. It isn't overstating to affirm that Nitrogen is the key component for metabolism and is the most critical ingredient of proteins and nucleic acids. Hence $\mathrm{N}_{2}$ assumes a huge role in the formation of biomolecules which control cellular activities. Incomprehensibly, all living organisms are in an ocean of environmental nitrogen (78\%), yet miserably not all life forms are supplied with the possibility to use this copiously accessible subatomic $\mathrm{N}_{2}$ reasonably. Just a few life forms like certain microorganisms, blue green algae and couple of organisms, have the probability to use atomic $\mathrm{N}_{2}$ adequately and to fix it in the atmosphere. In any case, the vast majority of plants are able to utilize different types of nitrogen without difficulty (5).

Similar to carbon, hydrogen and oxygen, nitrogen also has an indispensable role in a successful metabolism, as it is directly involved in growth and photosynthetic activity $(6,7)$. The required application of nitrogen to the plant always enhances the synthesis of chlorophyll, protein and protoplasm, thus it influences the cell shape, leaf texture and photosynthetic efficiency of plants (8). Secondary metabolites are the phytochemical that are produced as byproducts of mainly secondary metabolism (9). Recent investigations regarding the usefulness of these compounds have shown that secondary compounds such as alkaloids, terpenoids, phenols are either used for medicinal purposes or for taxonomic elucidation of species, i.e., chemotaxonmy $(10,11)$. This research work was designed to examine the impact of nitrogen supplements on the production of phytochemicals during drought condition and to explain the exogenous supply of nitrogen as a potential strategy for drought tolerant in $J$. curcas plants $(12,13)$. It was discovered during the study the consequence of exogenously supplied $\mathrm{N}_{2}$ enabled the plants to uphold defensive mechanism through the production of phytochemicals that assist the cell membrane to reduce the damaging effects caused by drought stress and to remain turgid during adverse conditions.

\section{Materials and Methods}

Plant growth and treatment: Jatropha curcas L. cuttings were procured from the biological garden in University of Lagos, Akoka, Nigeria. A total of 30 stems were sliced to a length of $24 \mathrm{~cm}$ prior to sowing in nylon bags filled with $1.5 \mathrm{~kg}$ soil. The seedlings were kept for 7 weeks between 3-7\% moisture content at $18{ }^{\circ} \mathrm{C}$ to enable sprouting and subsequent plant growth. The plants were then categorized into four groups: Control (C), Nitrogen supplement $(\mathrm{N})$, Nitrogen and drought $(\mathrm{N}+\mathrm{D})$ and only drought (D), which were then subjected to respective treatments for 2 weeks. Group 'C' served as a control and supplemented with $250 \mathrm{ml}$ tap water every day. Group ' $\mathrm{N}$ ' was supplemented with $0.1 \mathrm{M}$ foliar nitrogen at every $3^{\text {rd }}$ day, while plants of group ' $\mathrm{N}+\mathrm{D}$ ' were subjected to drought and $0.1 \mathrm{M}$ foliar nitrogen for the same duration and the plants of group 'D' were subjected to drought conditions for the duration of 2 weeks. After harvesting, all the plants were analyzed with triplicates and all the data was thoroughly compiled for further investigations.

Biomass determination: Harvested plants were washed thoroughly in running tap water to remove attached soil particles and debris, then rinsed twice with distilled water and placed in labeled paper bags to oven dry (at $65{ }^{\circ} \mathrm{C}$ for $72 \mathrm{~h}$ ) and then weighed (14).

Relative Water Content (RWC): The fourth leaf from top (fully expanded young leaf) of the plants representing each treatment were harvested and weighed to determine their fresh weight (FW). The leaves were submerged separately in distilled water for $24 \mathrm{~h}$ in the dark. They were collected from the water after this period, then dried using an absorbent and weighed to determine their saturated weight (SW). The leaves were then placed in paper bags and dried in an oven at $65{ }^{\circ} \mathrm{C}$ for $72 \mathrm{~h}$, following which the dry weight (DW) was recorded.

The relative water content was calculated according to Turner (15) using the formula:

Relative Water Content (\%) = [(fresh weight - dry weight $)$ / (saturated weight - dry weight)] x 100

Lipid Peroxidation Measurement: Lipid peroxidation was measured by estimation of malondialdehyde (MDA) content following the procedure of Wang and Jin (16). Fresh leaves (0.5 g) were homogenized in $5 \mathrm{ml} 20 \%$ trichloroacetic acid (TCA). The homogenate was centrifuged at $10000 \mathrm{~g}$ for $5 \mathrm{~min}$. The supernatant $(1 \mathrm{ml})$ was mixed with equal volume of $0.6 \% \quad(\mathrm{w} / \mathrm{v})$ thiobarbituric acid solution comprising $10 \%$ TCA. The mixture was incubated for $30 \mathrm{~min}$ in a boiling water bath and cooled quickly on ice bath. The absorbance of the mixture was read at 450, 532 and $600 \mathrm{~nm}$. The concentration of MDA was calculated as $6.45\left(\mathrm{~A}_{532}-\mathrm{A}_{600}\right)-0.56 \mathrm{~A}_{450}$. 


\section{Preliminary screening of $J$. curcas for Phytochemical contents}

Collection of Plant Material: The leaves of $J$. curcas were procured from the biological garden at the University of Lagos (Nigeria) and kept in a clean envelope. The leaves were washed and then air-dried to achieve a uniform weight.

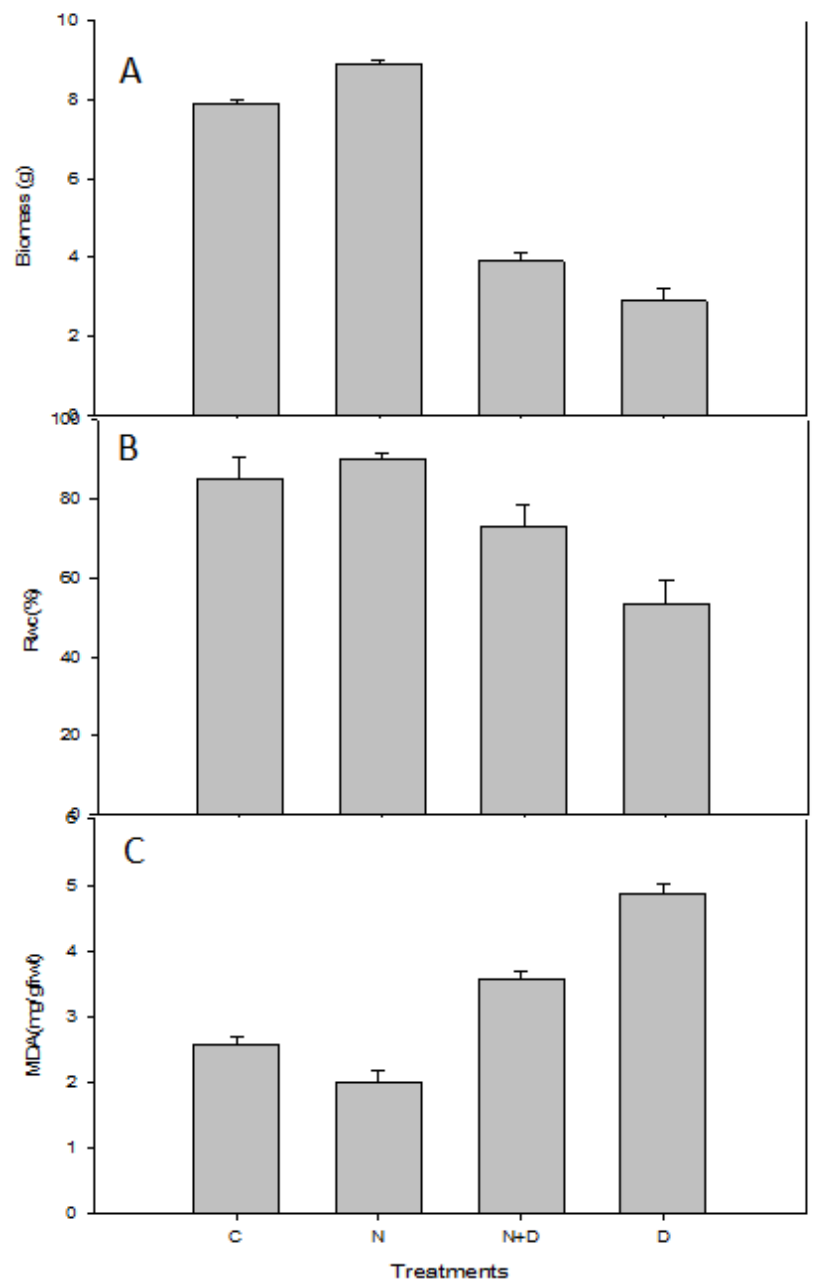

Fig. 1. Values of biomass (A), Relative water contents (B), MDA content (C) in J. curcas leaves after treatments. Mean \pm standard error $(n=3)$. C: Control; N: Nitrogen supplemented; $\mathrm{N}+\mathrm{D}$ : Nitrogen application with drought; D: Drought.

Preparation of Aqueous Extract: The air-dried leaves were ground into powder using mortar and pestle. The aqueous extracts of the leaf samples were made by soaking $5 \mathrm{~g}$ of the powdered sample in $10 \mathrm{ml}$ of distilled water for 12 hours (17). It was then filtered using Whatman filter paper no. 42, and the filtrate used for the analysis.

\section{Phytochemical Screening of the Aqueous Extracts of the leaves of Jatropha curcas}

The aqueous extracts of $J$. curcas were analyzed for the presence of flavonoids, saponins, terpenoids, tannins, alkaloids and phenols according to the standard methods as described by Harborne (18) and Trease and Evans (19).

\section{Statistical Analysis}

The outcomes are given as means $(n=3)$ of triplicates. All obtained data were evaluated by 16.0 SPSS program (SPSS Inc., Chicago, USA).

\section{Results}

Generally, drought stress significantly reduced the biomass of J. curcas. In plants with Nitrogen application, the biomass of $8.9 \pm 1.07 \mathrm{~g}$ was recorded which was greater than the control $(8.0 \pm 1.03 \mathrm{~g})$. In the case of plants under drought stress, the biomass value was $2.9 \pm 0.15 \mathrm{~g}$ whereas, a comparatively higher value of $4 \pm 0.1 \mathrm{~g}$ was recorded for plants under drought with nitrogen supplementation (Fig. 1A). Likewise, in case of RWC the obtained values represents similar trend, i.e., plants of group $\mathrm{C}, \mathrm{N}$ and $\mathrm{N}+\mathrm{D}$ showed RWC values as $85 \%, 90 \%$ and $73 \%$ respectively, that were significantly higher than RWC of plants (54\%) which were exposed to drought. Thus, the result indicated that the application of nitrogen is influential in the enhancement of relative water content (RWC) (Fig. 1B). However, the effect of drought stress showed a reverse trend in case of malondialdehyde contents (Fig. 1C). Plants with the Nitrogen treatment showed a reduced value of malondialdehyde compared to the control plants while plants subjected to drought showed higher values compared to drought with nitrogen supplementation. This showed that the application of nitrogen is helpful in lowering the malondialdehyde content during the stress conditions.

Table 1. The Qualitative analysis of phytochemical contents in Jatropha curcas

\begin{tabular}{lc} 
Alkaloids & ++ \\
\hline Saponins & ++ \\
\hline Terpenoids & + \\
\hline Tanins & ++ \\
\hline Flavonoids & ++ \\
\hline Phenols & + \\
\hline$+++=$ Very high, $++=$ moderate high,$+=$ low
\end{tabular}

The effects of nitrogen and drought on the phytochemical constituents of J. curcas are shown in Table 1 and Fig. 2. Alkaloid recorded a value of $267.33 \pm 8.7 \mathrm{mg} / 100 \mathrm{~g}$ in the control plant. While nitrogen supplemented plants showed the slightly elevated value of $(271 \pm 4.11 \mathrm{mg} / 100 \mathrm{~g})$ compared to control plants. The level of alkaloid was recorded least $(238 \pm 4.32 \mathrm{mg} / 100 \mathrm{~g})$ in drought exposed plants in comparison to nitrogen supplemented drought stressed plants, i.e., $245 \pm 8.7 \mathrm{mg} / 100 \mathrm{~g}$ (Fig. 2D).

Saponins were recorded more or less similar in all the four sets of the plants and the 


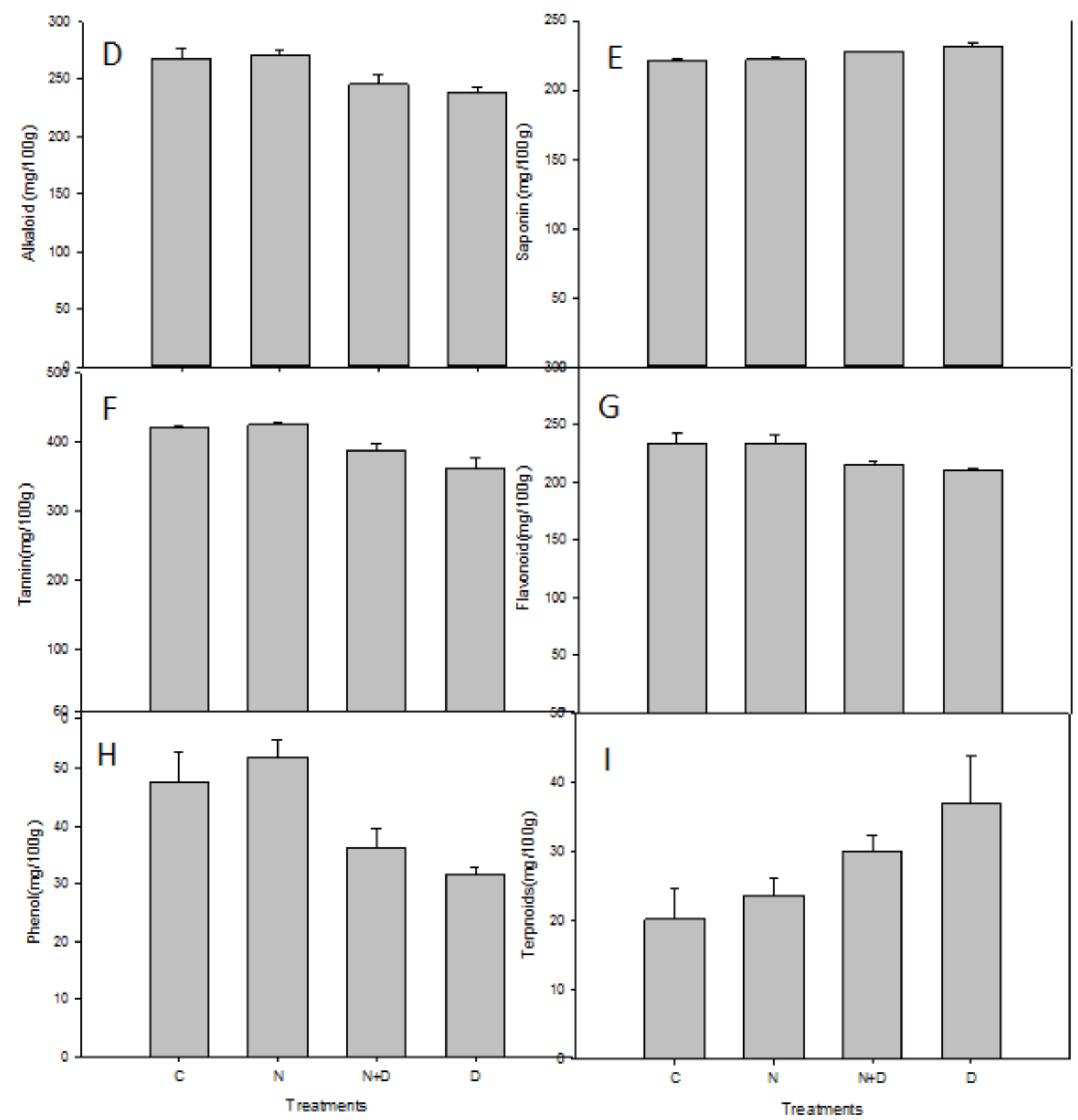

Fig. 2. Values of total alkaloid (D), saponin (E), tannin (F), flavonoid (G), phenol (H), and Terpenoid (I) contents in J. curcas leaves treatment. Mean \pm standard error $(n=3)$. C: Control; N: Nitrogen supplemented; $\mathbf{N}+\mathbf{D}$ : Nitrogen application with drought; D: Drought

content was maximum $(231 \pm 2.62 \mathrm{mg} / 100 \mathrm{~g})$ in plants exposed to drought stress, while least in control plants $(221.7 \pm 2.06 \mathrm{mg} / 100 \mathrm{~g})$, in the case of nitrogen supplemented plants the variations in saponin content between the second $(222 \pm 2.16 \mathrm{mg} /$ $100 \mathrm{~g})$ and the third group $(227 \pm 0.47 \mathrm{mg} / 100 \mathrm{~g})$ was fairly significant (Fig. 2E). For tannins, a value of $420.7 \pm 2.42 \mathrm{mg} / 100 \mathrm{~g}$ was recorded in the control plants, whereas $425.6 \pm 3.82, \quad 387.3 \pm 11.72$ and $363 \pm 15.13 \mathrm{mg} / 100 \mathrm{~g}$ were observed in plants expose to $\mathrm{N}, \mathrm{N}+\mathrm{D}$ and $\mathrm{D}$ respectively (Fig. 2F). The content of flavonoids in case of $\mathrm{N}$ supplemented plant was found slightly increased to a mean data value of $233 \pm 9.01 \mathrm{mg} / 100 \mathrm{~g}$ in contrast to control $(234 \pm 6.96$ $\mathrm{mg} / 100 \mathrm{~g})$ while $\mathrm{N}+\mathrm{D}(215 \pm 3.15 \mathrm{mg} / 100 \mathrm{~g})$ and $\mathrm{D}$ $(211.7 \pm 1.57 \mathrm{mg} / 100 \mathrm{~g})$ exhibited comparatively declined values than the control (Fig. 2G). Phenol estimation showed that due to the $\mathrm{N}$ application, the phenol content increased $(52 \pm 1.7 \mathrm{mg} / 100 \mathrm{~g})$ in the leaves than the control plants $(47.7 \pm 3.12$ $\mathrm{mg} / 100 \mathrm{~g}$ ) and this elevation was more significant when a comparison was made among the $\mathrm{N}, \mathrm{N}+\mathrm{D}$ $(36.3 \pm 1.96 \mathrm{mg} / 100 \mathrm{~g})$ and $\mathrm{D}(31.7 \pm 0.72 \mathrm{mg} / 100 \mathrm{~g})$ plants (Fig. 2H). Lastly, the terpenoids content showed a reverse trend with the highest value recorded in drought stressed plants $(37 \pm 3.86$ $\mathrm{mg} / 100 \mathrm{~g})$ followed by $\mathrm{N}+\mathrm{D}(30 \pm 1.24 \mathrm{mg} / 100 \mathrm{~g}), \mathrm{N}$ $(23.7 \pm 1.36 \mathrm{mg} / 100 \mathrm{~g})$ and the least $(20.2 \pm 2.51 \mathrm{mg} /$ $100 \mathrm{~g}$ ) for the control plants (Fig. 2I). The overall assessment had shown that the application of nitrogen to plants under drought stress has a positive role in the strengthening of defense response to drought against damaging effect on the cells. 


\section{Discussion}

Drought affects all the physiological and metabolic processes of the plants (20). These effects can be seen by the estimation of plant biomass, Relative water content, malondialdehyde (MDA) content. To withstand drought condition, plants shifted their metabolism towards the production of secondary metabolites to cope with the stress. These changes provide defense at the cell membrane, cell organelles and metabolic rate $(21,22)$. Various efforts have been made in the past to find out the exogenous supplements that can enhance the defense response of the plants. Nitrogen application is one such strategy (22). The increase in plant biomass due to the application of nitrogen might be related to nitrogen supply stimulating plant growth and productivity $(23,24)$. The reduction in percentage of relative water content (RWC) might be due to low moisture content in the soil, thus it affects water absorption by plant roots. This is in an agreement with the result reported by (25). In this study, a significant increase in nitrogen occurs due to the substrate which convert enzyme to nitrite, similar to earlier report by (26). The percentage RWC in N+D was found significantly higher compared to those exposed to only drought treatment, hence it indicates that nitrogen ameliorates the effects of drought. Similar results have been reported by (27). MDA activity is induced under drought, which results in the formation of ROS (28). The supply of nitrogen declined the effect of ROS on MDA concentration. The result might be associated with the importance of nitrogen in making use of energy and efficiency of photosynthesis (29). Quantitative investigation showed that alkaloids, saponins, tannins, phenols and terpenoids were present in the leaves of J. curcas. Drought (D) and Nitrogen + drought $(\mathrm{N}+\mathrm{D})$ treatments showed a remarkable impact on the concentrations of phytochemical. A low concentration of alkaloid, phenols, tannins and flavonoids were observed under $\mathrm{N}+\mathrm{D}$ treatment and $\mathrm{D}$. These are similar to the reports of (30) that ROS accumulates in plants under drought stress, thereby leading to the induction of oxidative damage. The high concentration of alkaloid, tannins, phenols and flavonoids found in plants under control and those supplied with exogenous nitrogen could be the role of plant nutrients in evaluating the activities of secondary metabolism production in plants (31). The study has recorded an increase in saponins and terpenoids in response to the effects of drought. These observations agree with the results obtained from (32) that showed that drought increased saponin content in Acalypha wilkesiana. In this study, this increase in saponins might suggest its defensive role against damage caused by oxidative stress (33-38). Drought stress is becoming a major global issue which restrict the agricultural productivity to a great extent. Nitrogen is an indispensable macronutrient for plants and it can influence many facets of plant development and metabolic pathways, including water relations and photosynthesis process (3941). This study showed that drought stress influenced the secondary metabolism of J. curcas, which resulted in a change in the concentrations of phytochemical, some of them are produced at higher concentrations than control while some synthesized lower than the control. The mineral like nitrogen was found helpful to attain better defense response to mitigate the effects of drought in the plant. It also indicates that there is an interraction between $\mathrm{N}$, water transport and drought stress in plants. Thus, the outcome of this study will be supportive in the future to strengthen the plants against drought stress.

\section{Conclusion}

The results showed the synergistic effect in nitrogen to mitigate drought stress in plants and revealed the utility of nitrogen application in $J$. curcas for better yield. The outcome of this study can be utilized in metabolic engineering approaches aimed at increasing the defense response which is associated with the improvement in growth and survival of plants, osmoregulation of the cytosolic compartments, ROS scavenging, membrane stabilization, balancing of membrane potential and induction of stress receptive genes that neutralize dysfunctions in metabolism caused by various stresses.

\section{Acknowledgements}

The authors wish to acknowledge the Department of Biochemistry, Lagos University Teaching Hospital for the usage of their laboratory and facilities.

\section{Author's contribution}

OV gave the idea, AA and IE performed the experiments and AA provided the relevant literatures and required inputs. All authors have read the manuscript.

\section{Competing Interest}

The authors have no competing interests.

\section{References}

1. Larcher W. Physiological Plant Ecology. Berlin: Springer-Verlag. 2003. https://doi.org/10.1007/978-3$\underline{662-05214-3}$

2. Wahid A, Rasul E. Photosynthesis in leaf, stem, flower and fruit. In: Pessarakli, $M$ (ed). Handbook of Photosynthesis. CRC Press, Florida. 2005. p. 479-497. https://doi.org/10.1201/9781420027877.sec8

3. Reddy AR, Chaitanya KV, Vivekanandan M. Droughtinduced response of photosynthesis and antioxidant 
metabolism in higher plants. Plant Physiology. 2004;161:1189-1202.

https://doi.org/10.1016/i.jplph.2004.01.013

4. Munné-Bosch S, Penuelas J. Photo and antioxidative protection and a role for salicylic acid during drought and recovery in field grown Phillyrea angustifolia plants. Planta. 2003;217:758-766. https://doi.org/10.1007/s00425-003-1037-0

5. $\mathrm{Xu} \mathrm{Z}$, Zhou G. Research advance in nitrogen metabolism of plant and its environmental regulation. The Journal of Applied Ecology. 2004;15(3):511-516

6. Freitas RG, Missio RF, Matos FS, Missio RF, Dias LAS. Development of seedlings of Jatropha under different doses of nitrogen. Revista Agrotecnologia. 2012;3:2435. https://doi.org/10.12971/2179-5959.v03n02a03

7. Laviola BG, Dias LAS. Nutrient concentration in $J$. curcas leaves and fruits and estimated extraction at harvest. Brazilian Journal of Soil Science. 2008;32:1969-1975. https://doi.org/10.1590/S0100$\underline{06832008000500018}$

8. Marschner H. Mineral Nutrition of Higher Plants, 2nd ed. Academic Press, London,U.K. 1995. p. 88.

9. Bako SP, Aguh BI. Phytochemical profiles of the Loranthacean mistletoes (Tapinanthus spp.) in relation to their hosts. Nigerian Journal of Botany. 2007;20(2):297-305.

10. Edeoga HO, Okwu DE, Mbaebie BO. Phytochemical constituents of some Nigerian medicinal plants. African Journal of Biotechnology. 2005;4(7):685-688. https://doi.org/10.5897/AJB2005.000-3127

11. Nyananyo BL, Gijo AH, Ogamba EN. The physicochemistry and distribution of Eichhornia crassipes on the river Nun in the Niger Delta. Journal of Applied Sciences and Environmental Management. 2007;11:133-137.

https://doi.org/10.4314/jasem.v11i3.55158

12. Annunziata MG, Ciarmiello LF, Woodrow P, Dell'Aversana E, Carillo P. Spatial and Temporal Profile of Glycine Betaine Accumulation in Plants Under Abiotic Stresses. Frontiers in Plant Science. 2019. https://doi.org/10.3389/fpls.2019.00230

13. Annunziata MG, Ciarmiello LF, Woodrow P, Maximova E, Fuggi A, Carillo P. Durum wheat roots adapt to salinity remodeling the cellular content of nitrogen metabolites and sucrose. Frontiers in Plant Science. 2017;7:2035. https://doi.org/10.3389/fpls.2016.02035

14. Causton DR. Plant growth analysis:A note on the variability of unit leaf rate within a sample. Annals of Botany. https://doi.org/10.1006/anbo.1994.1148 1994;74:513-518.

15. Turner NC, Wright GC, Siddique KHM. Adaptation of grain legumes (pulses) to water limited environments. Advances in Agronomy. 2001;71:123-231. https://doi.org/10.1016/S0065-2113(01)71015-2

16. Wang H, Jin JY. Photosynthetic rate, chlorophyl fluorescence parameters, and lipid peroxidation of maize leaves as affected by zinc deficiency. Photosynthetica. https://doi.org/10.1007/s11099-005-0092-0

17. Edeoga HO, Osuagwu GGE, Omosun G, Mbabie BO, Onwuka AS. Chemical Characteristics and utility of some Rubiaceous medicinal plants. Phytopharmacology and Therapeutic Values. 2009;23:79-87.
18. Harborne, JB. Phytochemical Methods: A guide to Modern techniques of Plant Analysis 2nd ed. Chapman and Hall, New York. 1973. p. 282.

19. Trease GE, Evans WC. Textbook of Pharmacognosy 12th ed. Tindall, London. 1989. p. 257.

20. Sofowora A. Medicinal plants and traditional medicine in Africa. Spectrum Books Ltd, Ibadan. 1993. p. 289.

21. Spollen WG, Sharp RE, Saab IN, Wu Y. Regulation of cell expansion in roots and shoots at low water potentials. In: Smith, JAC and H. Griffiths (eds).Water deficits, Plant Responses From Cell to Community. Bios Scientific Publishers, Oxford, UK. 1993.p. 37-52

22. Yin CY, Peng YH, Zang RG, Zhu YP. Adaptive responses of Populus kangdingensis to drought stress. Physiologia Plantarum. 2005;123: 445-451. https://doi.org/10.1111/j.1399-3054.2005.00477.x

23. Sapeta H, Costa JM, Lourenco T, Maronco J, Lendi P. Drought stress response in Jatropha curcas growth and physiology. Environmental and Experimental Botany. 2013;85:76-84. https://doi.org/10.1016/j.envexpbot.2012.08.012

24. Lawlor DW. Photosynthesis, productivity and environment. Journal of Experimental Botany. 1995;46:1449-1461.

https://doi.org/10.1093/jxb/46.special issue.1449

25. Joel G, Gamon JA, Field CB. Production efficiency in sunflower: the role of water and nitrogen stress. Remote Sensing of the Environment. 1997;62:176-188. https://doi.org/10.1016/S0034-4257(97)00093-X

26. Liu S, Jiang Y. Identification of differentially expressed genes under drought stress in perennial ryegrass. Physiologia Plantarum. 2010;139:375-387. https://doi.org/10.1111/j.1399-3054.2010.01374.x

27. Lips SH, Leidi EO, Silberbush M, Soares MIM, Lewis OAM. Physiological aspects of ammonium nitrate fertilization. Journal of Plant Nutrition. 1990;13:12711289. https://doi.org/10.1080/01904169009364151

28. Agarwal S, Sairam RK, Srivasta GC, Meena RC. Changes in antioxidant enzymes activity and oxidative stress by abscisic acid and salicylic acid in wheat genotypes. Biologia Plantarum. 2005;49(4):541-550. https://doi.org/ $\underline{10.1007 / \mathrm{s} 10535-005-0048-\mathrm{Z}}$

29. Wang H, Jin JY. Photosynthetic rate, chlorophyll fluorescence parameters, and lipid peroxidation of maize leaves as affected by zinc deficiency. Photosynthetica. https://doi.org/10.1007/s11099-005-0092-0

30. Kato MC, Hikosaka K, Hirotsu N, Makino A, Hirose T. The excess light energy that is neither utilized in photosynthesis nor dissipated by photoprotective mechanisms determines the rate of photo inactivation in photosystem II. Plant Cell Physiology. 2005;44:318325. https://doi.org/10.1093/pcp/pcg045

31. Sharma P, Jha AB, Dubey RS, Pessarakli M. Reactive oxygen species, oxidative damage, and antioxidant defense mechanism in plants under stressful conditions. Journal of Botany. 2012;21:1- 26. https://doi.org/10.1155/2012/217037

32. Aires A, Rosa E, Carvalho R. Effect of nitrogen and sulfur fertilization on glucosinin the leaves and roots of broccoli sprouts. Journal of Science and Food Agriculture. 2006;86:1512-1516. https://doi.org/10.1002/ jsfa. 2535

33. Odjegba VJ, Alokolaro AA. Simulated drought and salinity modulates the production of phytochemicals 
in Acalypha wilkesiana. Journal of Plant Studies. 2013;2:105-112. https://doi.org/10.5539/jps.v2n2p105

34. Lin K, Chao P, Yang C, Cheng W, Lo H, Chang T. The effects of flooding and drought stress on the antioxidant constituents in sweet potato leaves. Botanical Studies. 2006;47:417-426.

35. Okwu DE, Josiah C. Evaluation of the chemical composition of two Nigerian medicinal plants. African Journal of Biotechnology. 2006;5 (4):357-361.

36. Li H, Wang Z, Liu Y. Review in the studies on tannins activity of cancer prevention and anticancer. Journal of Chinese Medicinal Materials. 2003;26(6):444-448.

37. Ojo SKS, Esumeh FI, Osayinlusi SA, Jeje TO. Phytochemical antibacterial properties of Diodia scandes and Phyllanthus amarus on Staphylococci isolated from patients in tertiary hospitals in Nigeria. Journal of Medicinal Plants for Economic Development.2017;1(1):1-6.

https://doi.org/10.4102/jomped.v1i1.7
38. Wagner KH, Elmadfa I. Biological relevance of terpenoids, overview focusing on mono di- and tetraterpenes. Annals of Nutrition and Metabolism. 2003;47(3):95-106. https://doi.org/10.1159/000070030

39. Serraj R. Effects of drought stress on legume symbiotic nitrogen fixation: Physiological mechanisms. Indian Journal of Experimental Biology. 2003;41:1136-1141.

40. Xu G, Fan X, Miller AJ. Plant nitrogen assimilation and use efficiency. Annual Review in Plant Biology. 2012;63:153-182. https://doi.org/10.1146/annurevarplant-042811-105532

41. Ding L, Lu Z, Gao L, Guo S, Shen Q. Is Nitrogen a Key Determinant of Water Transport and Photosynthesis in Higher Plants Upon Drought Stress? Frontiers in Plant Science.

2018;9:1-11 